\title{
Gill lamellar pillar cell necrosis, a new birnavirus disease in Japanese eels
}

\author{
Nam-Sil Lee ${ }^{1}$, Yukihiro Nomura ${ }^{2}$, Teruo Miyazaki ${ }^{1, *}$ \\ ${ }^{1}$ Faculty of Bioresources, Mie University, 1515 Kamihama, Tsu, Mie 514-8507, Japan \\ ${ }^{2}$ Biotechnology Research Laboratories, Takara Shuzo Co., LTD. 3-4-1Seta, Otsu, Shiga 520-2193, Japan
}

\begin{abstract}
Since the late 1980s, a birnaviral gill disease has been occurring in Japanese eels Anguilla japonica reared in warmwater ponds in western regions in Japan. Diseased eels mostly displayed marked formations of aneurysmal hematomas within gill lamellae and high mortalities. Histological examination revealed necrosis of pillar cells and subsequent aggregation of erythrocytes inside the lamellar capillaries, and proliferation of interlamellar epithelia onto the lamellae. Gastric gland cells were also necrotized. Electron microscopy revealed birnavirus infection in lamellar pillar cells. The causative birnavirus was isolated and cultured in fish cell lines and was found to be related to an infectious pancreatic necrosis virus (IPNV) Sp serotype by neutralization tests. The viral pathogenicity was confirmed by the results of histopathological examinations and infectivity experiments.
\end{abstract}

KEY WORDS: Sp serotype birnavirus · Japanese eel Aneurysm in gill lamellae P Pillar cell necrosis . Gastric gland necrosis

\section{INTRODUCTION}

Infectious pancreatic necrosis virus (IPNV) is a wellknown aquatic birnavirus and was the first confirmed to be pathogenic to salmonid fishes (Wolf et al. 1960). Subsequently, birnaviruses were found all over the world in other fishes such as eels, yellowtail, turbot, goby, and shellfishes (Sano 1976, Adair \& Ferguson 1981, Hudson et al. 1981, Sorimachi \& Egusa 1982, Hedrick et al. 1985, 1986, Sorimach \& Hara 1985, Lo et al. 1988, Wattanavijan et al. 1988, Lipipun et al. 1989, Nova et al. 1993, Suzuki et al. 1998a, b). The serological relationships between IPNV and other aquatic birnaviruses were studied using cross-neutralization tests with polyclonal and monoclonal antibodies, which resulted in the establishment of 2 or 3 serogroups (Hill \& Way 1988, Wolf 1988, Caswell-Reno et al. 1989, Kusuda et al. 1993). Moreover, genogroups were proposed by amino acid sequence homology between IPNV strains and a marine birnavirus (MABV) group

- Addressee for correspondence.

E-mail:miyazaki@bio.mie-u.ac.jp
(Heppell et al. 1993, Hosono et al. 1996, Suzuki 1996) In the genogroups, Genogroup I includes WB (= VR299) serotypes of IPNV, Genogroup II includes Sp and $\mathrm{Ab}$ serotypes of IPNV, and the MABV genogroup includes MABV strains.

There have been reports of birnaviruses isolated from European eels Anguilla anguilla, and the isolates were classified as $\mathrm{Ab}$ and $\mathrm{Sp}$ serotypes of IPNV (Sano 1976, Cattric \& Chastel 1980, Bucke 1981, Okamoto et al. 1983) by neutralization tests with IPNV reference antisera. In previous studies, these birnaviruses were recognized to be either non-pathogenic or weakly pathogenic to eels although they were isolated from eels. In this study, we examined mass mortality in cultured Japanese eels suffering from gill lamellar aneurysms, which has been occurring since 1987 . We isolated a Sp serotype of birnavirus from the affected gills. Here we present the results of histopathological and electron microscopic studies, and report the isolation and culture of the causative birnavirus and the results of virological tests and infectivity experiments, which demonstrate a distinct pathogenicity to Japanese eel. 


\section{MATERIALS AND METHODS}

Diseased fish in natural outbreaks. Since 1987 , about 100 diseased eels ( 30 to $250 \mathrm{~g}$ ) with gill lamellar aneurysmal hematomas have been collected from natural outbreaks in warmwater farming ponds in Mie and Aichi Prefectures, Japan. After external and internal examination, they were used for histopathological and electron microscopic studies, and for virological examinations.

Cell lines and culture conditions. The following cell lines were used for examinations of viral affinity and isolation: RTG-2 (rainbow trout gonad), CHSE-214 (chinook salmon embryo), EPC (epithelioma papillosum cyprini), FHM (fathead minnow), EK-1 (eel kidney) and EO-2 (eel ovary). RTG-2, CHSE-214, EPC and FHM cells were cultured in Eagle's minimal essential medium (EMEM) containing $100 \mu \mathrm{g} \mathrm{ml}^{-1}$ of kanamycin and $10 \%$ foetal bovine serum (FBS) at $20^{\circ} \mathrm{C}$. EK-1 and EO-2 cells were cultured in Leibovitz's L-15 medium (L-15) with $10 \%$ FBS and kanamycin $\left(100 \mu \mathrm{g} \mathrm{ml}^{-1}\right)$ at $25^{\circ} \mathrm{C}$.

Virus isolation. Gill filaments with lamellae that had aneurysmal hematomas were excised and homogenized in 10 volumes of L-15 or EMEM. The homogenate was centrifuged at $2000 \times \mathrm{g}$ for $10 \mathrm{~min}$. The supernatant was filtered $(200 \mathrm{~nm})$ and the filtrate inoculated into the above cell lines in $25 \mathrm{~cm}^{2}$ flasks. Because the EK-1 cell line in L-15 with $2 \%$ FBS was appropriate for virus isolation and culture under the conditions that we used, virus cloning and virological examinations were conducted using EK-1 cells. The isolated virus was tentatively designated as PCNV (pillar cell necrosis virus), and was cloned by a limiting dilution method and used for virological examinations and infectivity experiments.

Viral characteristics. To determine the nucleic acid type of the virus, EK-1 cells were exposed to $10^{-4.0} \mathrm{M}$ IUdR (5-ido-2-deoxyuridine) or L-15 (control culture), and then infected with diluted virus and incubated at $25^{\circ} \mathrm{C}$. Ether sensitivity tests were conducted with $0.2 \mathrm{ml}$ of ethyl ether with addition of $1.8 \mathrm{ml}$ of virus suspension. This mixture and a control tube containing phosphate buffered saline (PBS) instead of ether were allowed to stand at $4^{\circ} \mathrm{C}$ for $18 \mathrm{~h}$. After removal of the ether by evaporation, the virus was titrated. To test the $\mathrm{pH}$ stability of the virus, virus suspensions were made in $\mathrm{L}-15$ adjusted to $\mathrm{pH} 3$ or $\mathrm{pH} 11$ for $3 \mathrm{~h}$ at $20^{\circ} \mathrm{C}$, and then the virus was titrated. For the control, the virus was suspended in $\mathrm{L}-15$ at $\mathrm{pH}$ 7.0. To determine the optimum temperature for virus replication, 5 monolayer cultures were prepared in $25 \mathrm{~cm}^{2}$ flasks and inoculated at a multiplicity of infection (MOI) of 0.01 virus cell $^{-1}$. The flasks were incubated at each selected temperature $\left(15,20,25,30\right.$ and $\left.35^{\circ} \mathrm{C}\right)$ for $6 \mathrm{~d}$, and virus titrations were conducted at established times. For the titration, a monolayer culture of EK-1 was prepared in 96-well microtitre plates and then the virus-containing media were diluted in serial 10 -fold steps from $10^{-1}$ to $10^{-8}$ An aliquot of each mixture $(0.05 \mathrm{ml})$ was then inoculated onto prepared cell culture plates. These were incubated at $25^{\circ} \mathrm{C}$, and the $50 \%$ infective end points were calculated after $7 \mathrm{~d}$.

Serological examination. Because virological examinations and electron microscopy (EM) revealed the isolated virus belonged to a birnavirus family, crossneutralization tests were performed with reference strains of IPNV (Ab, Sp and WB serotypes) and YAV (Y-6) (Yellowtail Ascites Virus, Kusuda et al. 1993), and the corresponding polyclonal rabbit antisera. An antiPCNV serum was prepared following to Okamoto et al. (1983) using a Japanese white rabbit (12 wk of age). Neutralizing titres were reciprocal of the antiserum dilution that protected $50 \%$ of the inoculated wells against the virus $100 \mathrm{TCID}_{50}$. The method of Archetti \& Horsfall (1950) was used to estimate the serological relatedness of the viruses.

Infectivity experiment. In previous studies, experimental infections with birnaviruses had failed when fish were inoculated by intraperitoneal and intramuscular injection. Based on the histopathological finding that virus infection mainly occurred in pillar cells of gill lamellae, we introduced an intramuscular injection at a point just posterior to the neck so that most of the injected virus would reach the target cells as rapidly as possible. Infectivity examinations using PCNV were conducted 3 times with carefully selected healthy eels. PCNV was propagated in EK-1 cells and the cell lysate was used for the inoculum. In the first trial (Trial 1), $15 \mathrm{fish}$ (average body weight, $40 \mathrm{~g}$ ) were injected with $10^{76} \mathrm{TCID}_{50} \mathrm{fish}^{-1}$. In the second trial (Trial 2), 11 fish (average body weight, $40 \mathrm{~g}$ ) were injected with $10^{\text {E. }}$ TCID $_{50}$ fish $^{-1}$ In the third trial (Trial 3), 21 fish (average body weight, $120 \mathrm{~g}$ ) were injected with $10^{8.6} \mathrm{TCID}_{50} \mathrm{fish}^{-1}$. Each trial had a control containing the same number of fish that were injected with L-15 only. After the inoculation, fish were held at $25^{\circ} \mathrm{C}$, and clinical signs and mortality were observed daily. Moribund and dead fish were processed for viral isolation and histological examinations.

Histopathological examinations and EM. The gills and visceral organs such as the Iivers, kidneys, spleens, digestive tracts, and hearts of naturally diseased eels and of moribund eels in the infectivity experiments were fixed in 10\% neutral buffered formalin or Bouin's solution for histopathological examinations. Tissue sections were stained with Meyer's hematoxylin and eosin (H\&E), Azan, Giemsa, Weigert's fibrin stain, and Periodic acid-Schiff (PAS) reaction. Moreover, on sections of the gill and stomach that 
revealed distinct histological degeneration, indirect fluorescent antibody tests (IFAT) were performed with an anti-PCNV serum in order to determine whether the virus was present. For EM, gill filaments and infected EK-1 cells were fixed in $3 \%$ glutaraldehyde in phosphate buffer, postfixed in $1 \%$ osmium tetroxide $\left(\mathrm{OsO}_{4}\right)$ and embedded in epoxy resin (Epon). Ultrathin sections were stained with uranyl acetate and lead citrate, and examined using a transmission electron microscope.

\section{RESULTS}

\section{External and internal signs of diseased eels}

Diseased eels in the natural outbreak and infectivity experiments usually lost their appetite and were weak but did not show any obvious external pathological signs. All fish internally displayed aneurysmal hematoma formations in gill lamellae followed by stasis of filamental arteries and partial filamental destruction (Fig. 1A).
Fig. 1 Anguilla japonica. Pathological signs of diseased eels in the natural outbreak. (A) Gill filaments have lamellae displaying the formation of aneurysms within the capillaries and the artery with stasis. (B) Pillar cells are necrotic and display nuclear karyorrhexis inside the lamellar capillaries Arrows point to representative necrotic cells. Erythrocytes conges tion has just begun within the capillary. Azan. (C) In a severe case gill lamellae extensively show necrosis of pillar cells and subsequent aneurysmal hematoma formations within the capillaries, and epithelial hyperplasia. Gill filament ( $g$ f) shows slight hemorrhage. Azan. (D) The stomach shows necrosis of gland cells where cells have subsequently been replaced with spaces lined by flat cells. Azan. Scale bars = $50 \mu \mathrm{m}$
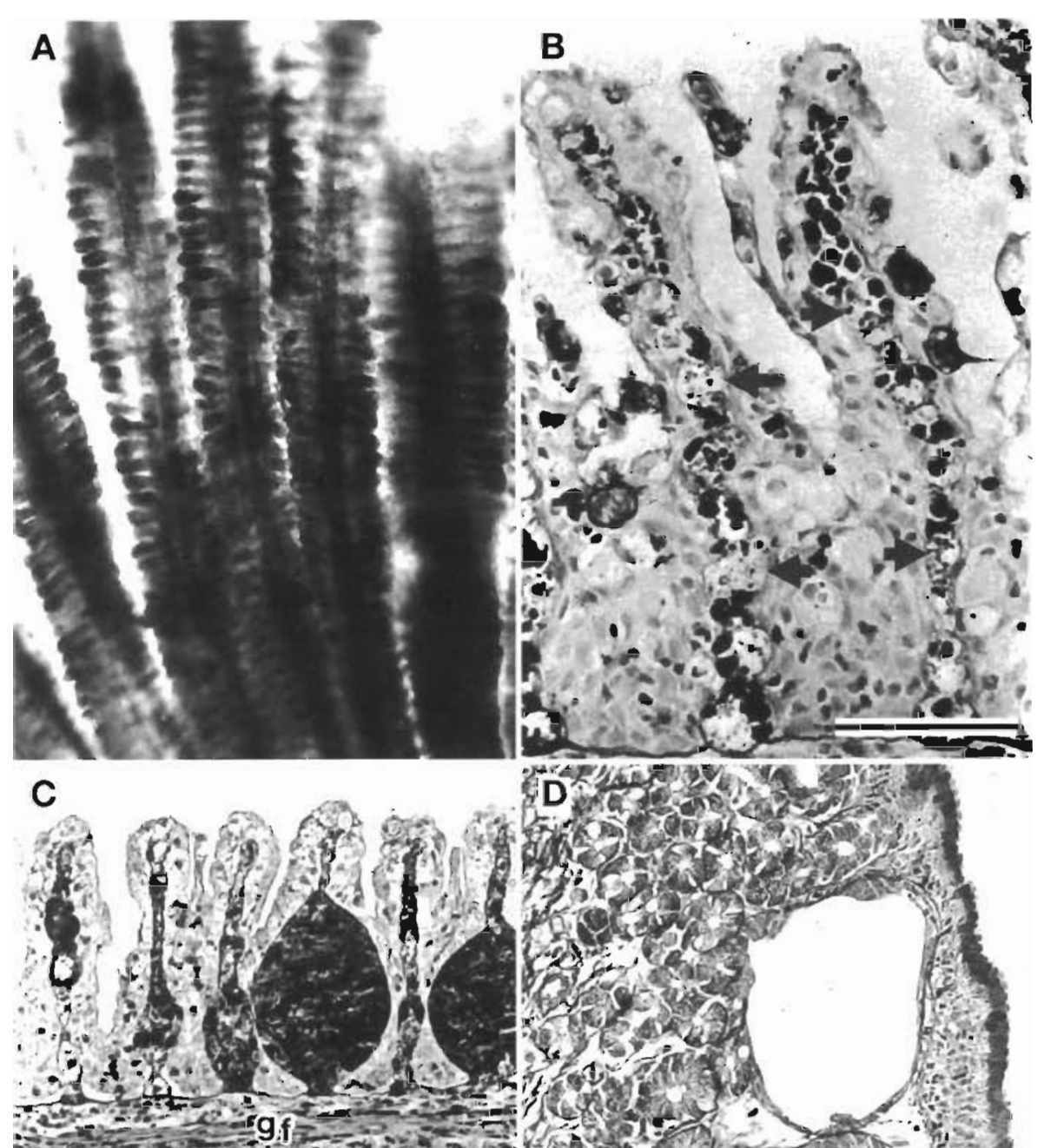

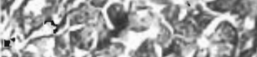

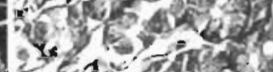
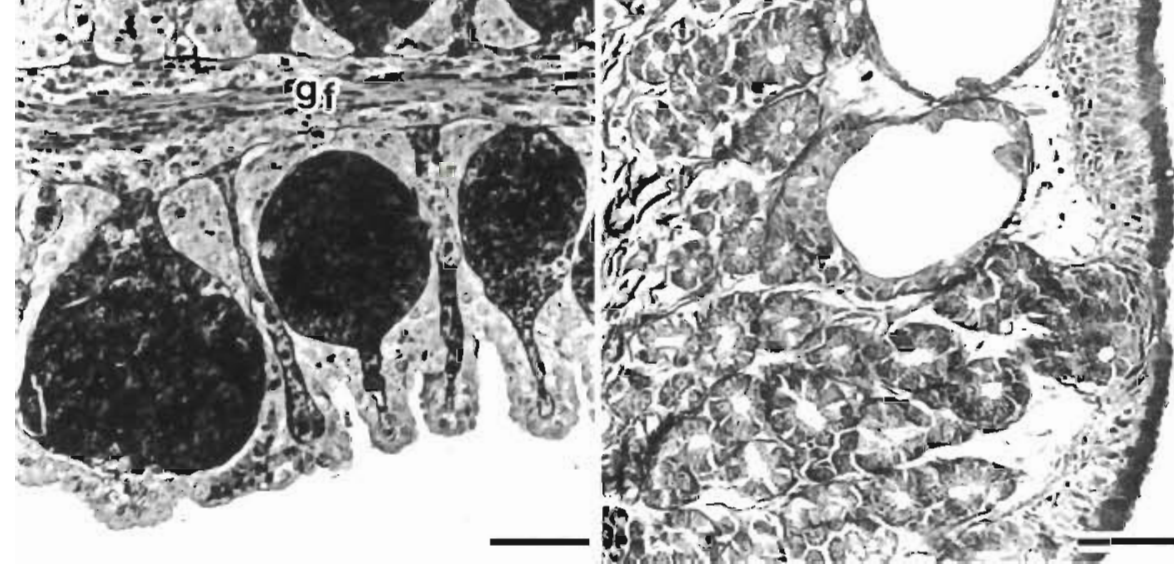

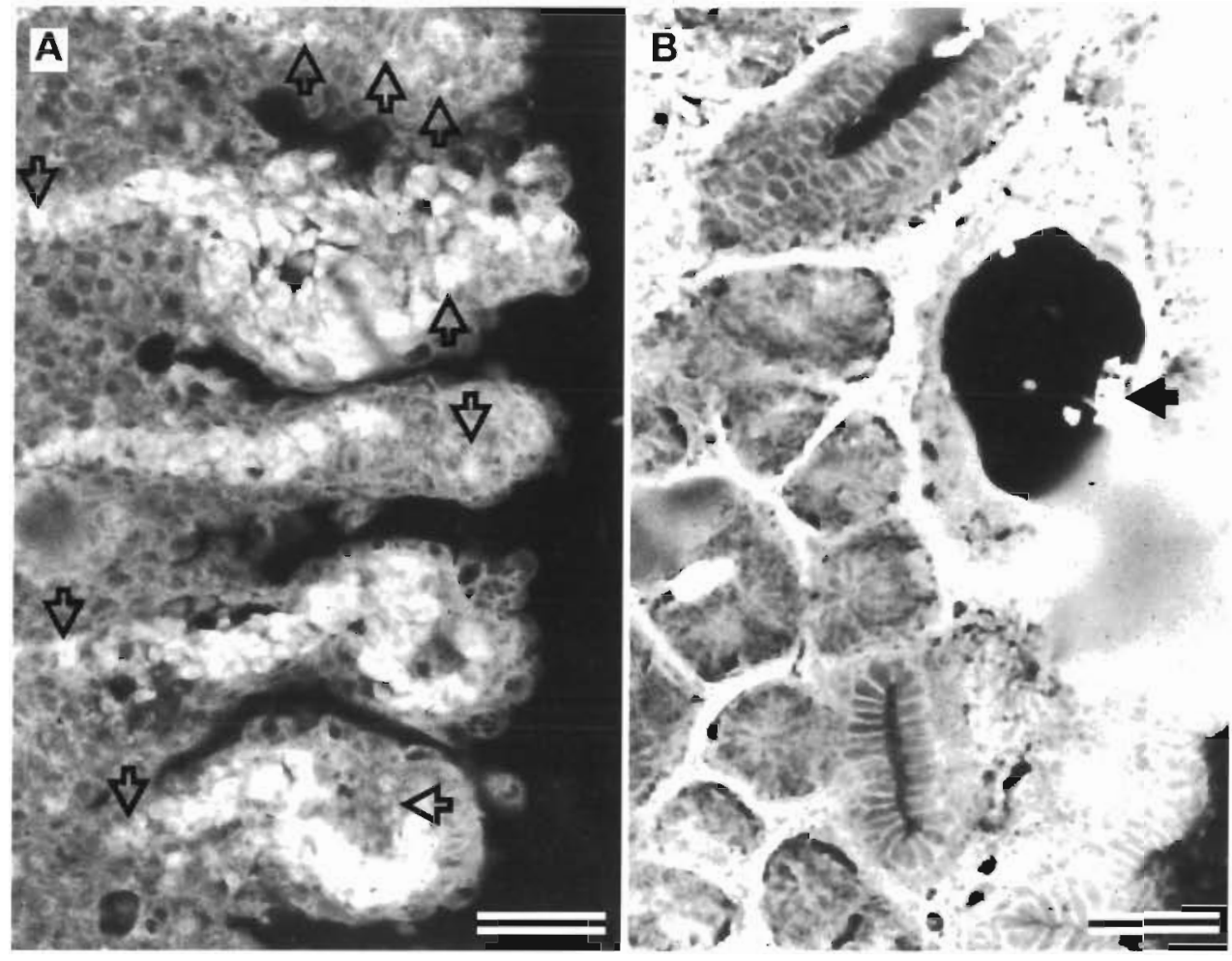

Fig. 2. Anguilla japonica. IFAT with an anti-PCNV rabbit serum. Scale bars = $50 \mu \mathrm{m}$. (A) Necrotized pillar cells show positive reactions (arrows) among packed erythrocytes which have autofluorescence inside lamellar capillaries. (B) Necrotized gland cells (arrow) display positive reactions within a space in the gland layer

\section{Histopathology and EM in diseased eels}

Most severe lesions were found in the gills. Gill lamellae had extensively necrotized pillar cells displaying karyorrhexis in the capillaries (Fig. 1B) where erythrocytes were slightly packed in the early stage. In these lamellae, erythrocytes subsequently became packed and caused the capillaries to expand, forming aneurysmal hematomas (Fig. 1C). Moreover, fibrin was sometimes deposited on the inner surface of the basal membrane of capillaries. These aneurysmal hematomas occurred partially in the affected lamellae or entirely in the lamellar capillaries. In lesions showing an aneurysmal hemtoma formation, the overlying respiratory epithelia exhibited hyperplasia, and erythrocytes sometimes infiltrated into hyperplastic epithelia and also into interlamellar epithelia. Gill filaments whose lamellae had aneurysmal hematomas often showed stasis of the filamental artery, and erythrocyte infiltration into the filamental connective tissue and the sinus. Fish that had gill lesions usually displayed necrosis of gastric gland cells in the stomach (Fig. 1D). These necrotic lesions contained necrotized gland cells or were replaced with empty spaces lined by flat cells in the gland tissue. IFAT with an anti-PCNV serum revealed positive reactions in necrotic pillar cells (Fig. 2A) and in necrotic gland cells (Fig. 2B). These diseased fish sometimes showed congestion or focal hemorrhage in the liver and kidney, but a histopathological change in the spleen, heart, or intestine were not obvious.

In EM, infected pillar cells displayed formation of electron-dense inclusions containing virus particles in the cytoplasm. Slightly affected cells maintained a normal-looking nucleus and organelles. However, severely affected cells displayed karyorrhexis, degenerating mitochondria and reticula, and subsequently a liquified cytoplasm (Fig. 3A). Myelin-like structures

Fig. 3. Anguilla japonica. Electron micrographs of the infected gill lamellae of a naturally diseased eel. (A) Infected pillar cell shows karyorrhexis (small arrowheads), electron-dense inclusions containing virus particles (large arrowheads) and a myelinlike structure in the amorphous cytoplasm. b: basal membrane, e: erythrocyte, n: neutrophil, r: respilatory epithelial cell. Scale bar $=2000 \mathrm{~nm}$. (B) High power view of virus particles. Nucleocapsids form within an electron-dense material. Doughnut-shaped capsids without the core of nuclic acid also appear. Scale bar $=200 \mathrm{~nm}$. (C) High power view of virus particles. Virions are distinct and separate from each other in a fragmented, electron-dense inclusion. The virion has a hexagonal outline with an electrondense core and a thick capsid. The edge-to-edge diameter is 62 to $75 \mathrm{~nm}$. m: a myelin-like structure. Scale bar $=200 \mathrm{~nm}$ 

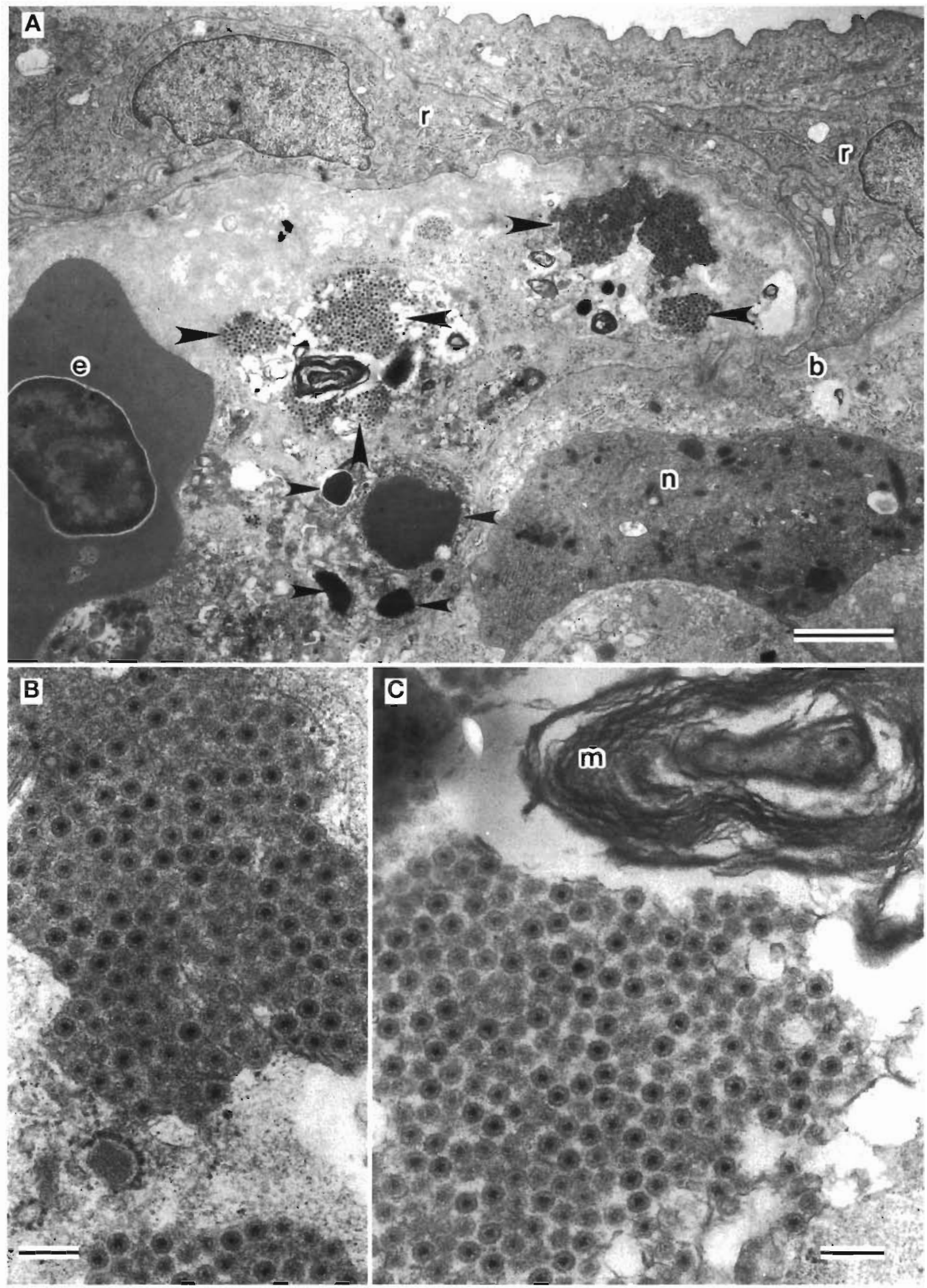

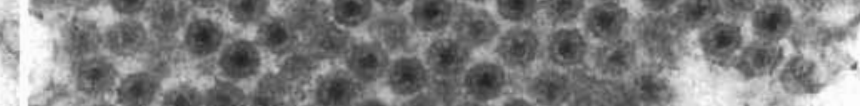

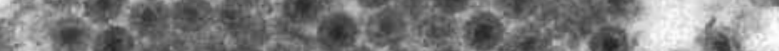

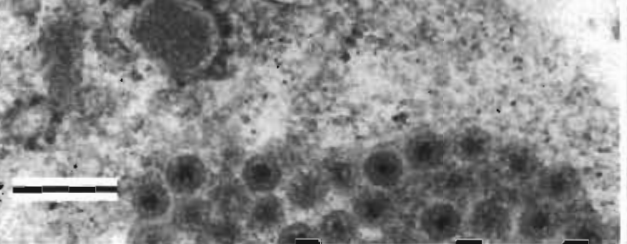

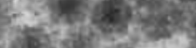

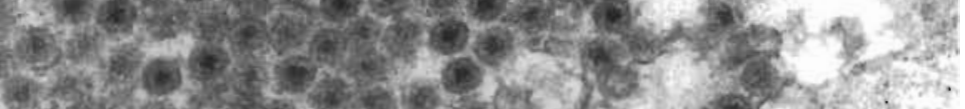

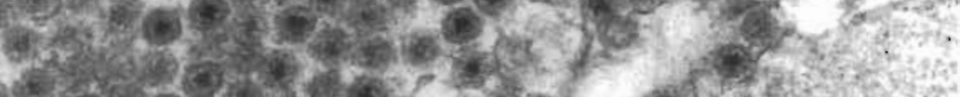

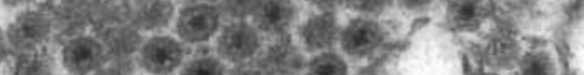


with hugh electron density were usually accompanied by the formation of inclusions contaning virus partıcles. These inclusions were the site of virion assembly, where small cores of nucleic acid initially formed. Then virions (nucleocapsids) were completed while empty capsids also formed (Fig. 3B). After the electrondense inclusions became fragmented, all of the virions became distinct and separated from each other
(Fig 3C). The virions had a hexagonal shape with an electron-dense core and a thick capsid. The edge-toedge diameter was 62 to $75 \mathrm{~nm}$. Especially in the natural outbreaks, respiratory epithelial cells were sometımes infected and displayed virion replication similar to that observed in pillar cells (Fig. 4A). These infected cells also had degenerated nuclei and organelles.

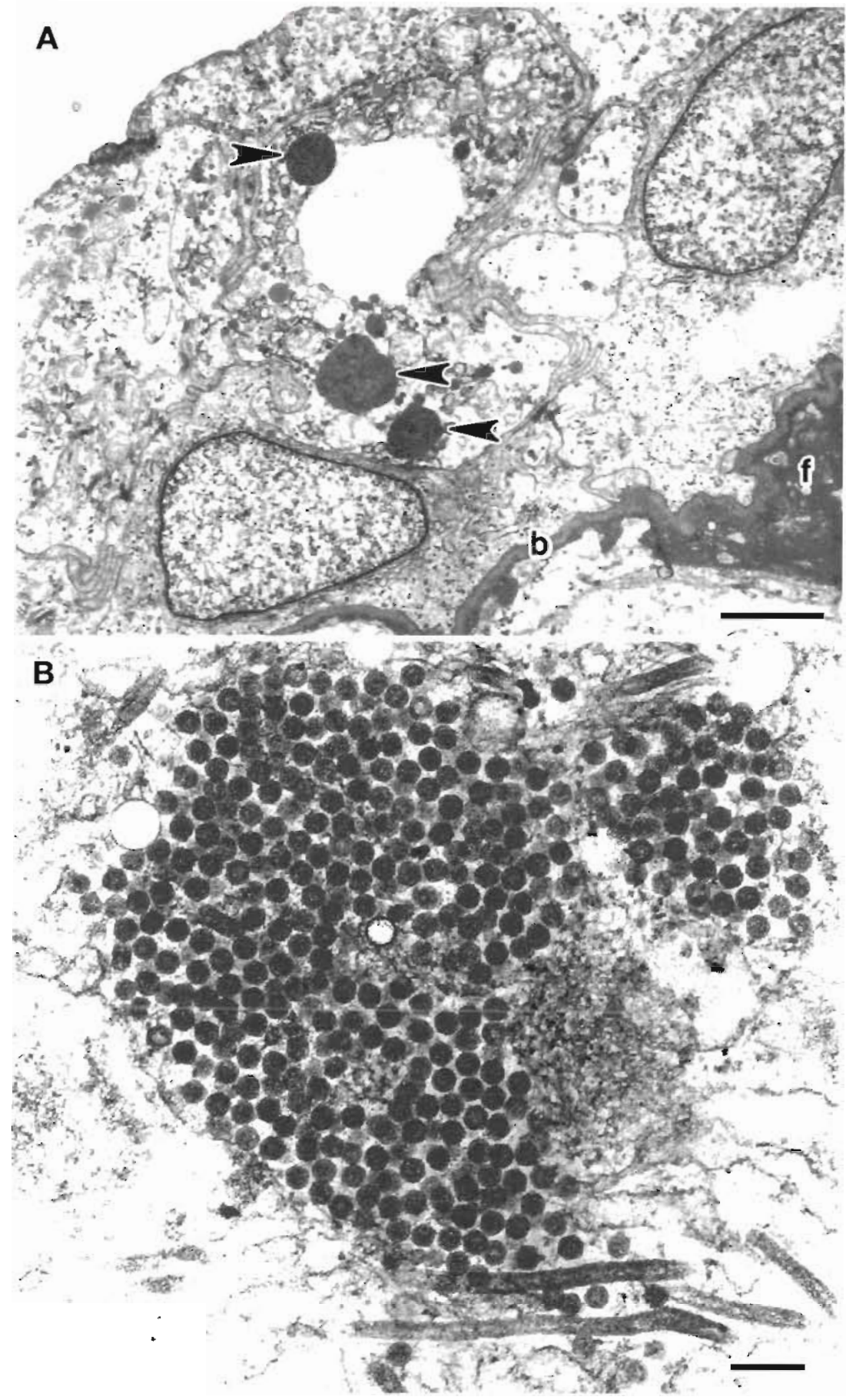

Fig. 4. Anguilla japonica. (A) Electron mucrograph of an infected respiratory epthelial cell. The cell exhibits electrondense inclusions containing cores of massive nucleic acid (arrowheads). swollen vesicles and mitochondria with destroyed cristae. f: deposited fibrin on the basal membrane (b) of a capillary. Scale bar $=2000 \mathrm{~nm}$. (B) Electron micrograph of an infected EK-1 cell. The cell displays multiplication of virions in large masses without formation of electrondense materials, tubular structures and thin fibers. Scale bar $=200 \mathrm{~nm}$ 
Table 1. Characteristics of isolated virus (PCNV)

\begin{tabular}{|c|c|c|}
\hline \multirow[t]{2}{*}{ Exposure to } & \multicolumn{2}{|c|}{$\log \operatorname{TCID}_{50} \mathrm{ml}^{-1}$} \\
\hline & Control & Treatment \\
\hline IUdR & 8.4 & 8.4 \\
\hline Ether & 8.4 & 8.6 \\
\hline $\mathrm{pH} 3$ & $8.3^{\circ}$ & 9.1 \\
\hline $\mathrm{pH} 11$ & & 8.3 \\
\hline
\end{tabular}

\section{Susceptibilities of cell lines}

All of the evaluated cell lines were susceptible to PCNV. EK-1, EO-2 and FHM cells showed the greatest sensitivity, and a cytopathic effect (CPE) was revealed by the presence of rounded cells showing karyopyknosis and of destroyed cells. CPE started forming from $4 \mathrm{~h}$ after virus inoculation and was completed within $24 \mathrm{~h}$. FHM, EPC, CHSE-214 and RTG-2 also showed the same CPE just after the initial isolation of the virus but were not affected by serial passage. In EM, infected EK-1 cells displayed multiplication of virions which appeared in large masses which were accompanied by tubular structures and thin fibers (Fig. 4B)

\section{Characteristics of the virus}

IUdR was not effective in blocking PCNV replication, indicating that the virus possesses an RNA genome. The titer with the ether treatment was similar to that of the control, revealing that the virus had no envelope. PCNV was stable under acid $(\mathrm{pH} 3)$ and alkaline (pH 11) conditions, and viral titres were maintained

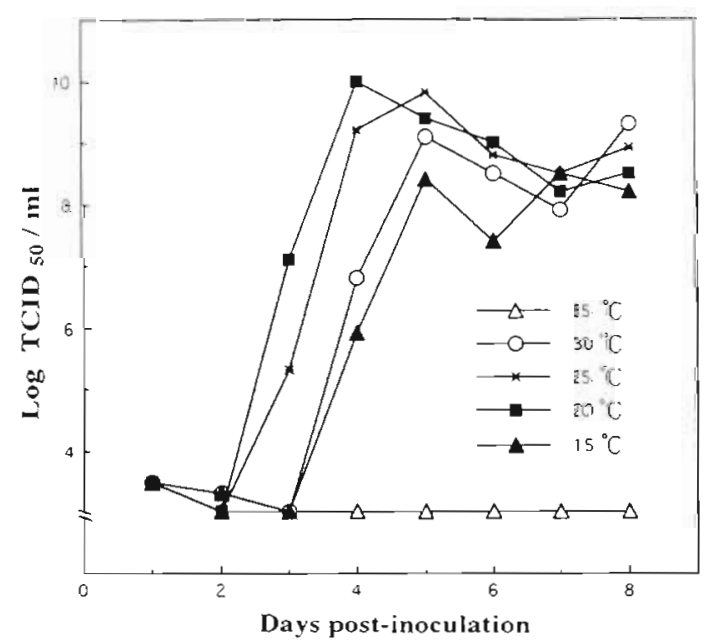

Fig. 5. Curves of virus titer released into the cultured medium from infected EK-1 cells inoculated with PCNV and incubated at selected temperature
Table 2. Neutralization titers of anti-PCNV serum against 4 reference strains and serological relationships of PCNV to 3 serotypes of IPNV by serum cross-neutralization tests. Data show reciprocal of the antiserum dilution protecting $50 \%$ of the test cultures against $100 \mathrm{TCID}_{50}$. Data in parentheses: $1 / \mathrm{r}$ value as described by Archetti \& Horsfall $(1950)_{i} r=\sqrt{r_{1} \times r_{2}}$ where $r_{1}$ and $r_{2}$ are the titer-ratios (heterologous titer divided by homologous titer for the respective antisera). ND: not determined

\begin{tabular}{|lcccc|}
\hline \multirow{2}{*}{$\begin{array}{l}\text { Virus } \\
\text { strain }\end{array}$} & PCNV & A.b & Sp & VR-299 \\
\hline PCNV & $7610(1)$ & $4697(3.2)$ & $18101(2.0)$ & $761(21.3)$ \\
Ab & 1745 & $10763(1)$ & ND & ND \\
Sp & 2808 & ND & $27917(1)$ & ND \\
VR-299 & 1131 & ND & ND & $51200(1)$ \\
YAV & 519 & ND & ND & ND \\
& & & & \\
\hline
\end{tabular}

with $10^{8.3}$ to $10^{9.1} \mathrm{TClD}_{50} \mathrm{ml}^{-1}$ (Table 1). PCNV grew well between 20 and $25^{\circ} \mathrm{C}$ and slowly at $15^{\circ} \mathrm{C}$. At $35^{\circ} \mathrm{C}$, virus replication was not observed $12 \mathrm{~h}$ after inoculation (Fig. 5).

\section{Neutralization tests}

Neutralization tests in which an anti-PCNV serum was reacted with the 3 serotypes of IPNV and YAV revealed that PCNV was related to the IPNV Sp and Ab serotypes. The results of cross-neutralization with the 3 reference strains of IPNV and PCNV, the $1 / \mathrm{r}$ values with serotypes of $\mathrm{Ab}, \mathrm{Sp}$ and $\mathrm{WB}$ were 3.2, 2.0 and 21.3 respectively (Table 2 ). The relatedness values (Archetti \& Horsfall 1950) showed that PCNV is more closely related to the $\mathrm{Sp}$ serotype than to the $\mathrm{Ab}$ serotype.

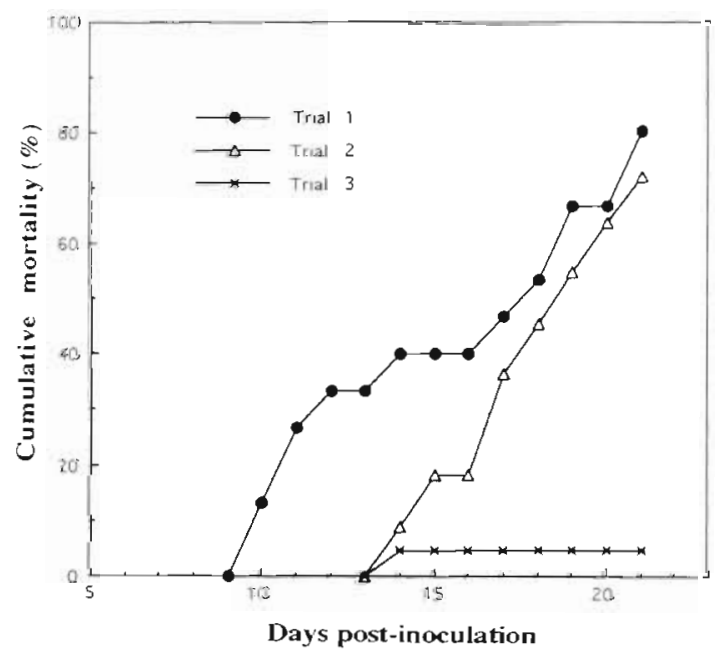

Fig. 6. Anguilla japonica. Cumulative mortalities of experimentally infected eels within the $3 \mathrm{wk}$ experimental period No mortalities occurred in control groups and, therefore, the graphs are omitted 


\section{Infectivity experiments}

The first deaths of inoculated fish occurred 10 and $14 \mathrm{~d}$ post-inoculation in Trials 1 and 2 respectively, and the cumulative mortalities reached 66.7 and $72.7 \%$ within the $21 \mathrm{~d}$ experimental period (Fig. 6). All inoculated fish including the moribund fish showed aneurysmal hematoma formation in gill lamellae and stasis of gill filamental arteries. Histopathological changes in the gill and stomach were mostly the same as those in the natural outbreaks, whereas the occurrence of stomach lesions was less than that in the natural outbreaks. The virus was re-isolated from diseased gill filaments at $10^{2.8-5.8} \mathrm{TCID}_{50} \mathrm{~g}^{-1}$. Only 1 moribund fish was recorded within 21 d in Trial 3, in which large eels were challenged. However, $75 \%$ of the inoculated fish displayed slight aneurysmal hematoma formation in gill lamellae and the virus was re-isolated from the gills at $10^{21-26} \mathrm{TCID}_{50} \mathrm{~g}^{-1}$. There were no mortalities and abnormalities in the corresponding control groups.

\section{DISCUSSION}

In the present study, a birnavirus was isolated from diseased eels with aneurysmal hematomas in gill lamellae. The birnavirus was revealed to be a $\mathrm{Sp}$ serotype of IPNV and its distinct pathogenicity was revealed by infection experiments. The experimental infection succeeded by means of an intra-muscular injection at a site just posterior to the neck. This method was proposed because histopathological and EM findings indicated that pillar cells were the main host cell. In the natural outbreaks and artificial infection, because of necrosis of the infected pillar cells, many erythrocytes were packed within lamellar capillaries, causing the subsequent formation of aneurysmal hematomas. Moreover, the resulting viremia could be expected to induce a virus infection of other organs, and in this case, gastric gland cell necrosis due to virus infection was confirmed, while in other organs necrosis due to viral infection was not apparent. Blood circulatory disturbances of gill lamellae would be expected to cause the mortality of diseased fish. In the case of natural outbreaks, it can be assumed that PCNV would initially infect respiratory epithelial cells as shown in Fig. 3A and spread to pillar cells, or directly invade pillar cells through the damaged respiratory epithelia, e.g. due to infestation of gill flukes.

It had been reported (Sano 1976, Cattric \& Chastel 1980, Bucke 1981, Okamoto et al. 1983, Chi et al. 1991) that birnavirus groups related to $\mathrm{Ab}$ and Sp serotypes of IPNV were isolated from European eels which might not have encountered salmonid fishes infected with IPNV, but any pathological effects were unclear be- cause of a lack of histological examinations in these previous studies. In the present study, a birnavirus of PCNV was isolated from Japanese eels that had never encountered salmonid fishes or European eels in Japan, and was revealed to be more closely related antigenically to the Sp rather than to the Ab serotype. PCNV revealed distinct pathogenicity, which confirms a pathogenicity of Sp serotype to the Japanese eel for the first time. Moreover, PCNV has never been shown to cause pancreatic necrosis in the Japanese eel in either naturally or experimentally infected cases, which is absolutely different from IPN in salmonids. Based on these results, the authors propose that this gill disease of the Japanese eel be called 'birnaviral pillar cell necrosis (BPCN)'.

Acknowledgements. The authors thank Dr H. Fukuda, Tokyo University of Fisheries, for kindly providing IPNV strains, and Dr S. Suzuki, Kochi University, for kindly providing us with a YAV strain and its antiserum. Antisera to serotypes of IPNV $\mathrm{Ab}, \mathrm{Sp}$ and VR-299 were obtained through the Japanese Fisheries Resource Conservation Association.

\section{LITERATURE CITED}

Adair BM, Ferguson HW (1981) Isolation of infectious pancreatic necrosis (IPN) virus from non-salmonid fish. J Fish Dis 4:69-76

Archetti I, Horsfall FL (1950) Persistent antigenic variation in influenza A viruses after incomplete neutralization in vivo with heterologous immune serum. J Exp Med 92:441-462

Bucke D (1981) A note on IPNV from eels in the U.K. Bull Eur Assoc Fish Pathologists 1:12

Castric J, Chastel C (1980) Isolation and characterization attempts of three viruses from European eel Anguilla anguilla preliminary results. Ann Virol (Inst Pasteur) 131E:435-448

Caswell-Reno P, Lipipun V, Reno PW, Nicholson BL (1989) Use of a group-reactive and other monoclonal antibodies in an enzyme immunodot assay for identification and presumptive serotyping of aquatic birnaviruses. J Clin Microbiol 27:1924-1929

Chi SC, Chen AN, Kou GH (1991) Establishment, characterization and application of monoclonal antibodies against eel virus European (EVE). Gyobyo Kenkyu (Fish Pathol) $26: 1-7$

Hedrick RP, Eaton WD, Fryer JL, Hah YC, Park JW, Hong SW (1985) Biochemical and serological properties of birnavirus isolated from fish in Korea. Fish Pathol 20:463-468

Hedrick RP, Eaton WD, Fryer JL, Groberg WC, Boonyaratpalin $\mathrm{S}$ (1986) Characteristics of a birnavirus isolated from cultured sand goby Oxyeleotris marmoratus. Dis Aquat Org 1:219-225

Heppell J, Berthiaume L, Corbin F, Tarrab E, Lecomte J, Arella M (1993) Comparison of amino acid sequences deduced from a cDNA fragment obtained from infectious pancreatic necrosis virus (IPNV) strains of different serotypes. Virology 195:840-844

Hill BJ, Way K (1988) Proposed standardization of the serological classification of aquatic birnaviruses. In: Abstracts of International Fish Health Conference, Vancouver, p 151

Hosono N, Suzuki S, Kusuda R (1996) Genogrouping of birnaviruses is isolation from marine fish: a comparison of 
VP2/NS junction regions on genome segment A. J Fish Dis 19:295-302

Hudson EB, Bucke D, Forrest A (1981) Isolation of infectious pancreatic necrosis virus from eels Anguilla anguilla L. in the United Kingdom. J Fish Dis 4:429-431

Kusuda R, Nishi Y, Hosono N, Suzuki S (1993) Serological comparison of birnaviruses isolated from several species of marine fish in South West Japan. Gyobyo Kenkyu IFish Pathol) 28:91-92

Lipipun V, Caswell-Reno P, Hsu YL, Wu JL, Tung MC, Reno PW, Wattanavijarn W, Nicholson BL (1989) Antigenic analysis of Asian aquatic birnavirus isolates using monoclonal antibodies. Fish Pathol 24:155-160

Lo CF, Hong YW, Huang SY, Wang CH (1988) The characteristics of the virus isolated from the gill of clam Meretrix lusoria. Fish Pathol 23:147-154

Nova B, Figueras A, Peuentes CF, Ledo A, Toranzo AE (1993) Characterization of a birnavirus isolated from diseased turbot cultured in Spain. Dis Aquat Org 15:163-169

Okamoto N, Sano T, Hedrick RP, Fryer JL (1983) Antigenic relationships of selected strains of infectious pancreatic necrosis virus (IPNV) and eel virus European (EVE). J Fish Dis 6:19-25

Sano T (1976) Viral diseases of cultured fishes in Japan. Fish Pathol 10:221-226

Editorial responsibility: $J_{O}$-Ann Leong,

Corvallis, Oregon, USA
Sorimachi M, Egusa S (1982) Characteristics and distribution of virus isolated from pond-cultured eels. Bull Natl Res Inst Aquaculture 3:97-105 (in Japanese)

Sorimachi M, Hara T (1985) Characteristics and pathogenicity of virus isolated from yellowtail fingerlings showing ascites. Fish Pathol 19:231-238

Suzuki S (1996) Molecularbiology of fish birnaviruses and its application. Virus 46:73-78 (in Japanese)

Suzuki S, Nakata T, Kamakura M, Yoshimoto M, Furukawa Y, Yamashita Y, Kusuda R (1998a) Isolation of birnavirus from Agemaki (jack knife clam) Sinonovacura consticta and survey of the virus using PCR technique. Fish Sci (Tokyo) 63:563-566

Suzuki S, Kamakura M, Kusuda R (1998b) Isolation of birnavirus from Japanese pearl oyster Pinctada fucata. Fish Sci (Tokyo) 64:342-343

Wattanavijan $\mathrm{W}$, Torchy $\mathrm{C}$, Tongtronpiros $\mathrm{J}$, de Kinkelin $\mathrm{P}$ (1988) Isolation of a birnavirus belonging to Sp serotye, from South East Asia Fish. Bull Eur Assoc Fish Pathol 8: $106-107$

Wolf K (1988) Fish viruses and fish viral diseases. Cornell University Press, Ithaca, London, $p 476$

Wolf K, Seniezko SF, Dunbar RCE, Pyle E (1960) Virus nature of infectious pancreatic necrosis in trout. Proc Soc Exp Biol Med 104:105-108

Submitted: September 28, 1998; Accepted: March 11, 1999 Proofs received from author(5): June 6, 1999 